\title{
Pentanuclear tetra-decker luminescent lanthanide Schiff base complexes $\dagger$
}

\author{
Xiaoping Yang, ${ }^{a}$ Richard A. Jones ${ }^{* a}$ and Wai-Kwok Wong $* b$ \\ Received 28th January 2008, Accepted 1st February 2008 \\ First published as an Advance Article on the web 20th February 2008 \\ DOI: $10.1039 / b 801513 a$
}

Luminescent pentanuclear tetra-decker $\mathrm{Ln}$ (III) complexes $\left[\mathrm{Eu}_{5} \mathrm{~L}_{4}(\mathrm{OH})_{2}\left(\mathrm{NO}_{3}\right)_{4}\left(\mathrm{H}_{2} \mathrm{O}\right)_{2}\right] \cdot \mathrm{NO}_{3} \cdot 3 \mathrm{H}_{2} \mathrm{O} \quad 1, \quad\left[\mathrm{Nd}_{5} \mathrm{~L}_{4}(\mathrm{OH})_{2}-\right.$ $\left.\left(\mathrm{NO}_{3}\right)_{5} \mathrm{MeOH}\right] \cdot 3 \mathrm{MeOH} \cdot 2 \mathrm{H}_{2} \mathrm{O} 2$ and $\left[\mathrm{Eu}_{5} \mathrm{~L}_{4}\left(\mathrm{CF}_{3} \mathrm{SO}_{3}\right)_{4}(\mathrm{MeO})_{2}-\right.$ $\left.\left(\mathrm{H}_{2} \mathrm{O}\right)_{4}\right] \cdot \mathrm{CF}_{3} \mathrm{SO}_{3} \cdot \mathrm{H}_{2} \mathrm{O} 3$ are formed from $\mathrm{Ln}\left(\mathrm{NO}_{3}\right)_{3} \cdot 6 \mathrm{H}_{2} \mathrm{O}$ $(\mathrm{Ln}=\mathrm{Eu}$ (1), $\mathrm{Nd}(2))$ and $\mathrm{Eu}\left(\mathrm{CF}_{3} \mathrm{SO}_{3}\right)_{3}$, respectively $\left(\mathrm{H}_{2} \mathrm{~L}=N, N^{\prime}\right.$-bis(5-bromo-3-methoxysalicylidene)phenylene1,2-diamine).

Self-assembled polynuclear lanthanide(III) complexes have recently attracted much attention because of their potential use in materials science and as probes in biology. ${ }^{1}$ For the lanthanide ions the $\mathrm{f}-\mathrm{f}$ transitions are parity forbidden which results in very low absorption coefficients. In order to overcome this, suitable chromophors have been used to act as antennas or sensitizers which can transfer energy to the lanthanide ion indirectly. ${ }^{2}$ The photophysical properties of $\operatorname{Ln}(\mathrm{III})$ ions therefore depend on their ligand environments which can be designed to protect the metal center from solvent molecules which can quench emissions. However, lanthanide coordination chemistry is challenging. It is characterized by high coordination numbers and flexible coordination geometries and structures often depend on a variety of factors such as ionic radius, the nature of counter anions and the metal-to-ligand ratio. ${ }^{3}$

Our recent studies have focused on the use of a variety of "salen" style Schiff base ligands to stabilize Ln(III) centers and to provide the antenna for lanthanide luminescence. ${ }^{4}$ An interesting emerging feature exhibited by these complexes is the self-assembly of stacked "multi-decker" structures in which Ln(III) ions are sandwiched between alternating layers of the Schiff base ligand. For example the reaction of bis(5-bromo-3-methoxysalicylidene)phenylene1,2-diamine $\left(\mathrm{H}_{2} \mathrm{~L}\right)$ with $\mathrm{TbCl}_{3} \cdot 6 \mathrm{H}_{2} \mathrm{O}$ produces both "tetra-decker" $\left(\left[\mathrm{Tb}_{3} \mathrm{~L}_{4}\right]^{+}\right)$and "triple-decker" $\left(\left[\mathrm{Tb}_{3} \mathrm{~L}_{3}\right]^{3+}\right)$ architectures depending on the nature of the anions present during their formation. ${ }^{4 f}$ These studies raised a number of interesting questions. For example, is it possible to construct larger multidecker multimetallic lanthanideSchiff base assemblies by careful adjustment of stoichiometry, anion selection and reaction conditions? As part of our continuing studies focused on the assembly of these multi-decker systems we describe here the syntheses, structures and photophysical properties of three new pentametallic tetra-decker complexes of

aDepartment of Chemistry and Biochemistry, The University of Texas at Austin, 1 University Station A5300, Austin, Texas, 78712-0165, USA. E-mail: rajones@mail.utexas.edu; Fax: +1 (512) 471-6822; Tel: +1 (512) 471-1706

${ }^{b}$ Chemistry Department, Hong Kong Baptist University, Kowloon Tong, Hong Kong, P. R. China. E-mail: wkwong@hkbu.edu.hk; Fax: +8523411 7348; Tel: +85234117075

$\uparrow$ CCDC reference numbers 670094-670096. For crystallographic data in CIF or other electronic format see DOI: 10.1039/b801513a

Electronic supplementary information (ESI) available: ${ }^{1} \mathrm{H}$ NMR spectrum of 2. See DOI: $10.1039 / \mathrm{b} 801513 \mathrm{a}$
$\mathrm{Eu}(\mathrm{III})$ and $\mathrm{Nd}$ (III) formed from reactions of $\mathrm{Ln}\left(\mathrm{NO}_{3}\right)_{3} \cdot 6 \mathrm{H}_{2} \mathrm{O}$ $(\mathrm{Ln}=\mathrm{Eu}, \mathrm{Nd})$ and $\mathrm{Eu}\left(\mathrm{CF}_{3} \mathrm{SO}_{3}\right)_{3}$ (Scheme 1). The compounds are the first examples of $\left[\mathrm{Ln}_{5} \mathrm{~L}_{4}\right]^{7+}$ stacked multidecker lanthanideSchiff base complexes.
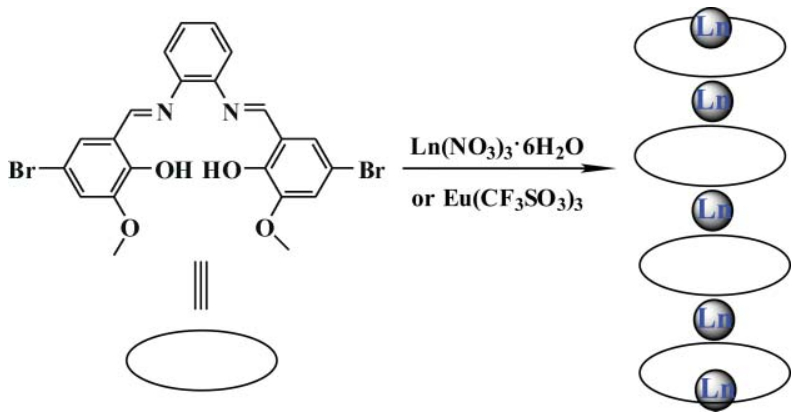

Scheme 1 Self-assembly of pentanuclear tetra-decker lanthanide complexes.

Reaction of $\mathrm{H}_{2} \mathrm{~L}$ with $\mathrm{Ln}\left(\mathrm{NO}_{3}\right)_{3} \cdot 6 \mathrm{H}_{2} \mathrm{O}$ (4:5) in refluxing $\mathrm{MeOH}$ in the presence of $\mathrm{Et}_{3} \mathrm{~N}$ gave the pentanuclear complexes $\left[\mathrm{Eu}_{5} \mathrm{~L}_{4}(\mathrm{OH})_{2}\left(\mathrm{NO}_{3}\right)_{4}\left(\mathrm{H}_{2} \mathrm{O}\right)_{2}\right] \cdot \mathrm{NO}_{3} \cdot 3 \mathrm{H}_{2} \mathrm{O} \quad \mathbf{1}$ and $\left[\mathrm{Nd}_{5} \mathrm{~L}_{4}(\mathrm{OH})_{2}\left(\mathrm{NO}_{3}\right)_{5} \mathrm{MeOH}\right] \cdot 3 \mathrm{MeOH} \cdot 2 \mathrm{H}_{2} \mathrm{O}$ 2.tई $\mathrm{A}$ view of the cationic moiety of $\mathbf{1}$ is shown in Fig. 1. The two outer $\mathrm{Eu}^{3+}$ ions, $\mathrm{Eu}(1)$ and $\mathrm{Eu}(5)$, have similar nine-coordinate environments and each is bound to the $\mathrm{O}_{2} \mathrm{O}_{2}$ cavities of the outer Schiff base ligand and surrounded by nine oxygen atoms from one L group, one bidentate $\mathrm{NO}_{3}{ }^{-}$anion, one bridged $\mathrm{NO}_{3}{ }^{-}$anion, one $\mathrm{OH}^{-}$ anion and one $\mathrm{H}_{2} \mathrm{O}$ molecule. The two inner $\mathrm{Eu}^{3+}$ ions, $\mathrm{Eu}(2)$ and $\mathrm{Eu}(4)$, also have similar nine-coordinate environments comprising the $\mathrm{N}_{2} \mathrm{O}_{2}$ donor set of one outer $\mathrm{L}$ group, the $\mathrm{O}_{2} \mathrm{O}_{2}$ set of one inner $\mathrm{L}$ group and one bridged $\mathrm{NO}_{3}{ }^{-}$anion. The central $\mathrm{Eu}(3)$

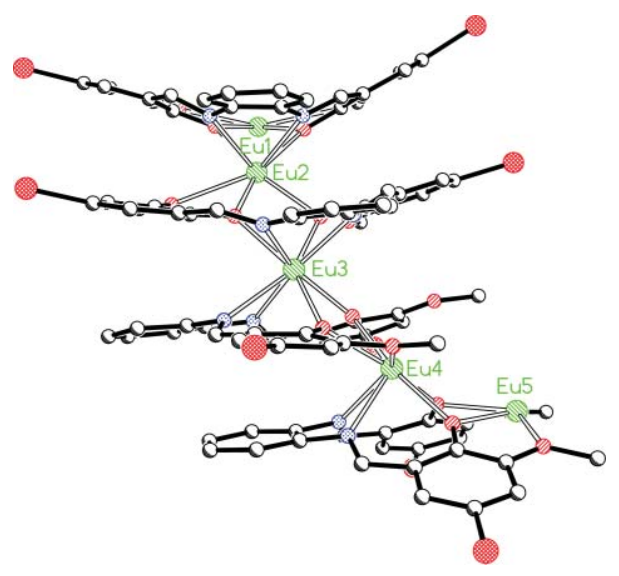

Fig. 1 Crystal structure of 1 showing general ligand configurations. Coordinated $\mathrm{NO}_{3}{ }^{-}$and $\mathrm{OH}^{-}$anions, $\mathrm{H}_{2} \mathrm{O}$ molecules and $\mathrm{H}$ atoms have been omitted for clarity. 
ion has an eight-coordinate pseudo-square based antiprismatic geometry formed by the two $\mathrm{N}_{2} \mathrm{O}_{2}$ donor sets of the internal L ligands. The Eu-Eu separations are similar at $3.704 \AA$ and $3.700 \AA$ for $\mathrm{Eu}(1)-\mathrm{Eu}(2)$ and $\mathrm{Eu}(4)-\mathrm{Eu}(5)$, respectively, and $3.925 \AA$ and $3.912 \AA$ for $\mathrm{Eu}(2)-\mathrm{Eu}(3)$ and $\mathrm{Eu}(4)-\mathrm{Eu}(3)$, respectively. In 2, the three inner $\mathrm{Nd}^{3+}$ ions $(\mathrm{Nd}(2), \mathrm{Nd}(3)$ and $\mathrm{Nd}(4))$ have coordination environments similar to the inner $\mathrm{Eu}^{3+}$ ions in 1, while two outer $\mathrm{Nd}^{3+}$ ions $(\mathrm{Nd}(1)$ and $\mathrm{Nd}(5))$ have slightly different sets of coordinating ligands (Fig. 2). For $\mathrm{Nd}(1)$ one methanol molecule replaces the coordinated $\mathrm{H}_{2} \mathrm{O}$ molecule in $\mathbf{1}$, and for $\mathrm{Nd}(5)$ an additional bidentate $\mathrm{NO}_{3}{ }^{-}$anion, results in a coordination number of ten. The differences between $\mathbf{1}$ and $\mathbf{2}$ could be due to the larger ionic radius of $\mathrm{Nd}^{3+} v s$. $\mathrm{Eu}^{3+}$. The $\mathrm{Nd}-\mathrm{Nd}$ separations are similar at $3.937 \AA$ and $3.940 \AA ̊$ for $\mathrm{Nd}(2)-\mathrm{Nd}(3)$ and $\mathrm{Nd}(3)-\mathrm{Nd}(4)$, respectively, while they are $3.660 \AA$ and $3.744 \AA$ for $\mathrm{Nd}(1)-\mathrm{Nd}(2)$ and $\mathrm{Nd}(4)-\mathrm{Nd}(5)$, respectively.

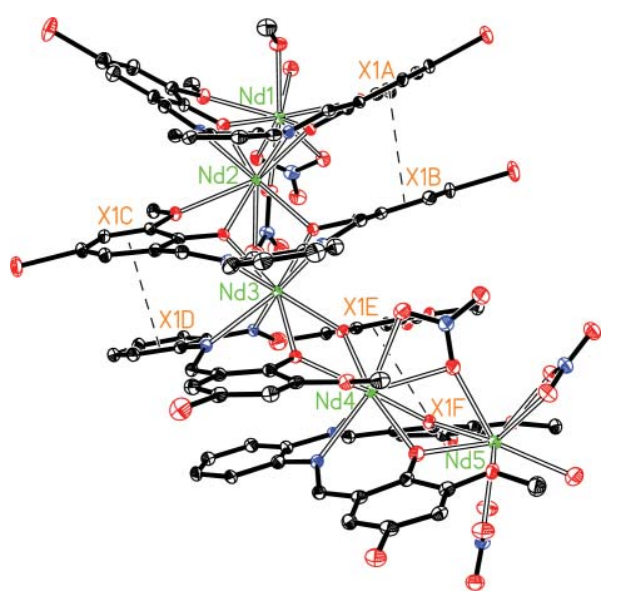

Fig. 2 A view of the molecular structure of 2. Hydrogen atoms are omitted for clarity and thermal elipsoids drawn at the $25 \%$ probability level. Intramolecular $\pi-\pi$ stacking interactions: X1A $\cdots$ X1B: $3.705 \AA$, X1C ‥X1D: $3.619 \AA$ Å, X1E ‥X X1F: $3.731 \AA$.

Reaction of $\mathrm{H}_{2} \mathrm{~L}$ with $\mathrm{Eu}\left(\mathrm{CF}_{3} \mathrm{SO}_{3}\right)_{3}$ gave the pentanuclear complex $\left[\mathrm{Eu}_{5} \mathrm{~L}_{4}\left(\mathrm{CF}_{3} \mathrm{SO}_{3}\right)_{4}(\mathrm{MeO})_{2}\left(\mathrm{H}_{2} \mathrm{O}\right)_{4}\right] \cdot \mathrm{CF}_{3} \mathrm{SO}_{3} \cdot \mathrm{H}_{2} \mathrm{O} 3$ which has a similar pentanuclear tetra-decker structure to $\mathbf{1}$ and $\mathbf{2}$. A view of the cationic moiety of $\mathbf{3}$ is shown in Fig. 3. The framework contains a $C_{2}$ axis running through the central $\mathrm{Eu}(3)$ ion which has the same eight-coordinate environment as that in $\mathbf{1}$. For each of the equal inner eight-coordinate $\mathrm{Eu}^{3+}$ ions $\left(\mathrm{Eu}(2)\right.$ and $\left.\mathrm{Eu}(2)^{*}\right)$, one bridged $\mathrm{MeO}^{-}$anion replaces the bridging $\mathrm{NO}_{3}{ }^{-}$anion in $\mathbf{1}$. For each of the equal outer nine-coordinate $\mathrm{Eu}^{3+}$ ions $(\mathrm{Eu}(1)$ and $\left.\mathrm{Eu}(1)^{*}\right)$, two monodentate $\mathrm{CF}_{3} \mathrm{SO}_{3}{ }^{-}$anions and one $\mathrm{H}_{2} \mathrm{O}$ molecule replace the $\mathrm{NO}_{3}{ }^{-}$and $\mathrm{OH}^{-}$anions in $\mathbf{1}$. The distances of $\mathrm{Eu}(1)$ $\mathrm{Eu}(2)$ and $\mathrm{Eu}(2)-\mathrm{Eu}(3)$ are $3.636 \AA$ and $4.037 \AA$, respectively. In all three complexes, the phenolic oxygen atoms of the Schiff base ligands $\mathrm{L}$ are bridging and the methoxy oxygen atoms and nitrogen atoms of $\mathrm{L}$ group are monodentate. In 1-3 the inner two $\mathrm{L}$ ligands are virtually planar while the outer two L ligands display a curved bowl-like configuration. A similar ligand arrangement was observed in the $\mathrm{Tb}$ multidecker complexes $\left[\mathrm{Tb}_{3} \mathrm{~L}_{4}\right]^{+}$and $\left[\mathrm{Tb}_{3} \mathrm{~L}_{3}\right]^{3+4 f}$ The dihedral angles between these rings range from 121.9 to $149.5^{\circ}$. Intramolecular $\pi-\pi$ stacking interactions between phenylene units are found in 1-3. The distances between adjacent aryl units range from $3.511 \AA$ to $3.802 \AA$ (Fig. 2).

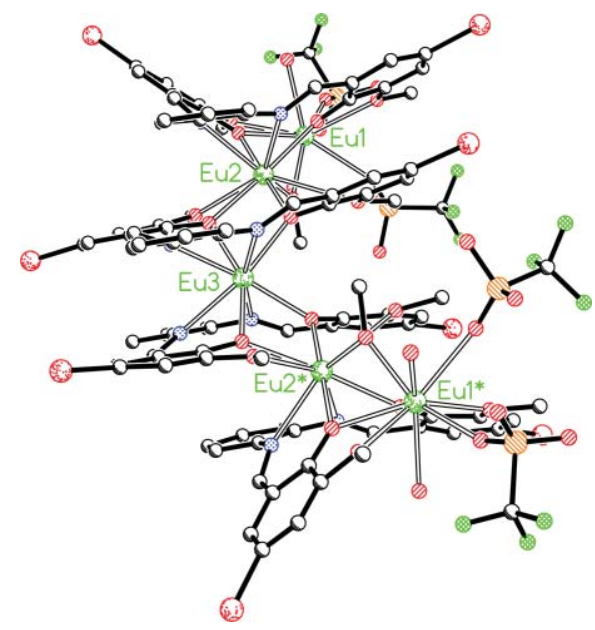

Fig. 3 Crystal structure of $\mathbf{3}$ showing general ligand configurations. $\mathrm{H}$ atoms have been omitted for clarity. Symmetry operator: $\left(-x, y, \frac{1}{2}-z\right)$ is used to generate $\mathrm{Eu}^{*}$ atoms.

The ${ }^{1} \mathrm{H}$ NMR spectrum of $\mathbf{2}$ in $\mathrm{CD}_{3} \mathrm{CN}$ contains multiple broad peaks ranging from -21 to $+46 \mathrm{ppm}$ (Fig. S1, ESI $\dagger$ ). The photophysical properties of 1-3 have been studied in $\mathrm{CH}_{3} \mathrm{CN}$. UVVis spectra show that absorption bands of the free ligand $\mathrm{H}_{2} \mathrm{~L}$ are red-shifted on metal ion coordination in 1-3 (Fig. 4). The excitation and emission spectra of $\mathbf{1}$ and emission spectrum of 2 are shown in Fig. 5 and Fig. 6, respectively. Upon excitation of the ligand centered (L) absorption band, $\mathbf{1}$ and $\mathbf{3}$ show visible emission bands typical of the $\mathrm{Eu}^{3+}$ ion $\left({ }^{5} \mathrm{D}_{0} \rightarrow{ }^{7} \mathrm{~F}_{j}\right.$ transitions, $j=$ 1, 2, 3 and 4), and 2 shows NIR luminescence of $\mathrm{Nd}^{3+}$ ion $\left({ }^{4} \mathrm{~F}_{3 / 2} \rightarrow\right.$ ${ }^{4} \mathbf{I}_{j / 2}$ transitions, $j=9,11,13$ ). The ligand centered ${ }^{1} \pi-\pi^{*}$ emission was not detected in either $\mathbf{1}$ or $\mathbf{3}$. The fluorescence quantum yields $\left(\Phi_{\mathrm{em}}\right)$ of $\mathbf{1}$ and $\mathbf{3}$ in $\mathrm{CH}_{3} \mathrm{CN}$ are 0.084 and 0.077 , respectively, ${ }^{5}$ while the NIR luminescence quantum yield of $\mathbf{2}$ could not be measured due to instrumental limitations. The absence of typical $\mathrm{Eu}^{3+}$ ion excitation bands in the excitation spectra and the ligand-centered luminescence in the emission spectra of $\mathbf{1}$ and $\mathbf{3}$ indicates that the ligand-to-metal energy transfer takes place efficiently. ${ }^{6}$

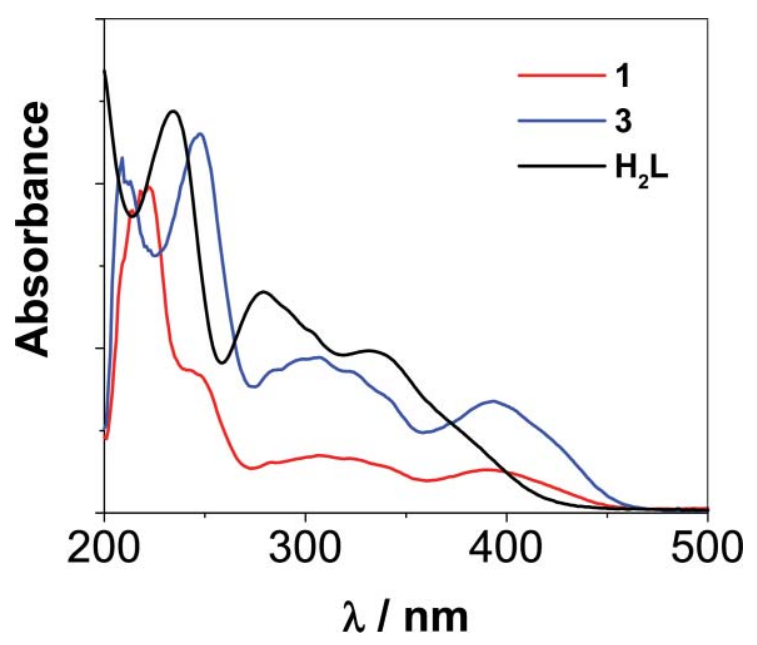

Fig. 4 UV-Vis spectra of free $\mathrm{H}_{2} \mathrm{~L}$ and complexes $\mathbf{1}$ and $\mathbf{3}$ in $\mathrm{CH}_{3} \mathrm{CN}$. 


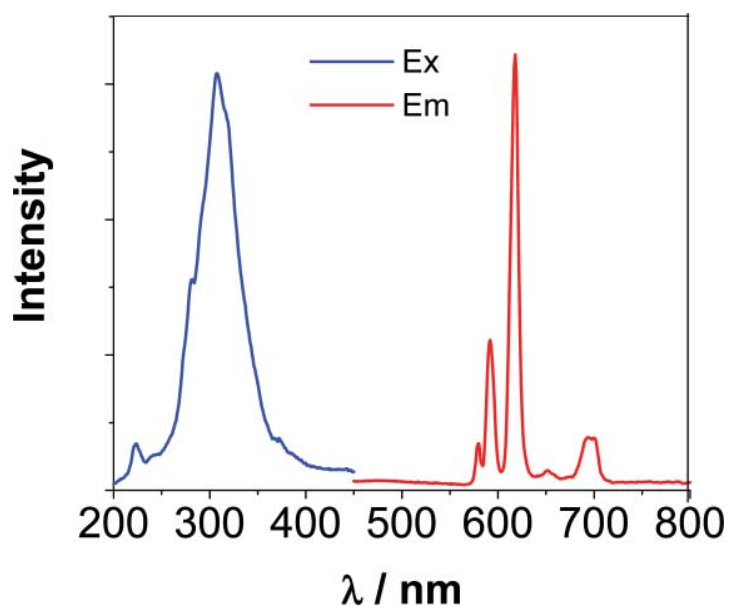

Fig. 5 The excitation and emission spectra of 1 in $\mathrm{CH}_{3} \mathrm{CN}\left(1 \times 10^{-6} \mathrm{M}\right)$ at room temperature.



Fig. 6 NIR luminescence of 2 in $\mathrm{CH}_{3} \mathrm{CN}\left(1 \times 10^{-6} \mathrm{M}\right)$ at room temperature.

\section{Acknowledgements}

We thank the Robert A. Welch Foundation (Grant F-816), the Texas Higher Education Coordinating Board (ARP 0036580010-2006), The Petroleum Research Fund, administered by the American Chemical Society (47014-AC5) and the Hong Kong Research Grants Council (HKBU 202407) for support.

\section{Notes and references}

$\ddagger$ Experimental procedure: The Schiff base ligand $\mathrm{H}_{2} \mathrm{~L}$ was prepared according to well-established procedures. ${ }^{7}$ For 1 triethylamine $(4 \mathrm{~mL}$ of $0.1 \mathrm{M}$ MeCN solution) was added to a solution of $\mathrm{H}_{2} \mathrm{~L}(0.106 \mathrm{~g}, 0.20 \mathrm{mmol})$ and $\mathrm{Eu}\left(\mathrm{NO}_{3}\right)_{3} \cdot 6 \mathrm{H}_{2} \mathrm{O}(0.107 \mathrm{~g}, 0.25 \mathrm{mmol})$ in $30 \mathrm{~mL}$ of $\mathrm{MeOH}$. The resulting solution was stirred and refluxed for $30 \mathrm{~min}$. The color of the solution changed from red to yellow during reflux. The mixture was then cooled to room temperature and filtered. Diethyl ether was allowed to diffuse slowly into this solution at room temperature and yellow single crystals were obtained in one week. Yield $0.085 \mathrm{~g}(50 \%) . \mathrm{Mp}>330{ }^{\circ} \mathrm{C}$ (decomp.). ESI-MS $\left(\mathrm{CH}_{3} \mathrm{CN}\right) \mathrm{m} / \mathrm{z}: 1013\left[\mathrm{M}-3 \mathrm{NO}_{3}{ }^{-}-7 \mathrm{H}_{2} \mathrm{O}\right]^{3+}$. IR
$\left(\mathrm{CH}_{3} \mathrm{CN}, \mathrm{cm}^{-1}\right): 3379,3370,2843,2395,2014,1654,1279,1221,1172$, $1098,1029,763,665,637$. For $\mathbf{2}$ the procedure was the same as that for $\mathbf{1}$ using $\mathrm{Nd}\left(\mathrm{NO}_{3}\right)_{3} \cdot 6 \mathrm{H}_{2} \mathrm{O}$. Yellow single crystals of 2 were formed in one week. Yield $0.100 \mathrm{~g}(59 \%)$. $\mathrm{Mp}>335^{\circ} \mathrm{C}$ (decomp.). ESI-MS $\left(\mathrm{CH}_{3} \mathrm{CN}\right) \mathrm{m} / \mathrm{z}$ : $1180\left[\mathrm{M}-3 \mathrm{NO}_{3}{ }^{-}-4 \mathrm{MeOH}-2 \mathrm{H}_{2} \mathrm{O}\right]^{3+} .{ }^{1} \mathrm{H}$ NMR $\left(400 \mathrm{MHz}, \mathrm{CD}_{3} \mathrm{CN}\right)$ : $\delta(\mathrm{ppm})-20.407(3 \mathrm{H}),-5.319(2 \mathrm{H}),-4.218(10 \mathrm{H}),-2.890(2 \mathrm{H}),-1.495$ $(2 \mathrm{H}),-1.107(2 \mathrm{H}),-0.625(2 \mathrm{H}), 0.479(2 \mathrm{H}), 1.188(9 \mathrm{H}), 1.257(9 \mathrm{H}), 3.118$ $(6 \mathrm{H}), 3.496(6 \mathrm{H}), 4.497(2 \mathrm{H}), 11.344(4 \mathrm{H}), 14.499(6 \mathrm{H}), 29.279(4 \mathrm{H}), 38.275$ (9H), 45.654 (2H). IR ( $\left.\mathrm{CH}_{3} \mathrm{CN}, \mathrm{cm}^{-1}\right): 3352,2879,2382,1658,1251,1220$, $1176,1099,1028,765,665$. For 3 the procedure was the same as that for 1 using $\mathrm{Eu}\left(\mathrm{CF}_{3} \mathrm{SO}_{3}\right)_{3}$. Yellow single crystals of $\mathbf{3}$ were formed in two weeks. Yield $0.119 \mathrm{~g}(63 \%)$. $\mathrm{Mp}>350{ }^{\circ} \mathrm{C}($ decomp. $)$. ESI-MS $\left(\mathrm{CH}_{3} \mathrm{CN}\right) \mathrm{m} / z$ : $1081\left[M-3 \mathrm{CF}_{3} \mathrm{SO}_{3}{ }^{-}-4 \mathrm{H}_{2} \mathrm{O}\right]^{3+}$. IR $\left(\mathrm{CH}_{3} \mathrm{CN}, \mathrm{cm}^{-1}\right): 3342,2945,2831$, 2361, 1658, 1511, 1470, 1409, 1311, 1237, 1196, 1106, 1025, 816, 739, 665. $\S$ Crystal data for $1: \mathrm{C}_{88} \mathrm{H}_{66} \mathrm{Br}_{8} \mathrm{~N}_{13} \mathrm{O}_{38} \mathrm{Eu}_{5}$, triclinic, space group P $\overline{1}, a=$ $17.300(3), b=18.267(4), c=20.124(4) \AA, a=75.52(3)^{\circ}, \beta=87.75(4)^{\circ}$, $\gamma=74.48(3)^{\circ}, V=5930(2) \AA^{3}, Z=2, D_{\mathrm{c}}=1.855 \mathrm{~g} \mathrm{~cm}^{-3}, \mu($ Mo$\mathrm{K} \alpha)=5.381 \mathrm{~mm}^{-1}, F(000)=3168, T=153 \mathrm{~K} . R_{1}=0.0775, w R_{2}=$ 0.2127 for 20848 independent reflections with a goodness-of-fit of 1.060. For 2: $\mathrm{C}_{92} \mathrm{H}_{82} \mathrm{Br}_{8} \mathrm{~N}_{13} \mathrm{O}_{39} \mathrm{Nd}_{5}$, triclinic, space group $P \overline{1}, a=16.878(3)$, $b=19.282(4), c=22.601(5) \AA, \alpha=96.53(3)^{\circ}, \beta=102.92(4)^{\circ}, \gamma=$ $104.75(3)^{\circ}, V=6818(2) \AA^{3}, Z=2, D_{\mathrm{c}}=1.634 \mathrm{~g} \mathrm{~cm}^{-3}, \mu($ Mo-K $\alpha)=$ $4.287 \mathrm{~mm}^{-1}, F(000)=3234, T=153 \mathrm{~K} . R_{1}=0.0709, w R_{2}=0.2027$ for 23946 independent reflections with a goodness-of-fit of 1.067. For 3 : $\mathrm{C}_{95} \mathrm{H}_{70} \mathrm{Br}_{8} \mathrm{~F}_{15} \mathrm{~N}_{8} \mathrm{O}_{38} \mathrm{~S}_{5} \mathrm{Eu}_{5}$, monoclinic, space group $C 2 / c, a=24.973(5)$, $b=23.003(6), c=23.628(5) \AA, \beta=105.21(3)^{\circ}, V=13098$ (5) $\AA^{3}, Z=$ $4, D_{\mathrm{c}}=1.915 \mathrm{~g} \mathrm{~cm}^{-3}, \mu($ Mo-K $\alpha)=4.977 \mathrm{~mm}^{-1}, F(000)=7240, T=$ 153 K. $R_{1}=0.0488, w R_{2}=0.1354$ for 11510 independent reflections with a goodness-of-fit of 1.045. All data were collected on a Nonius Kappa CCD diffractometer and structures solved using the program SHELXL$97 .{ }^{8}$ CCDC reference numbers 670094-670096. For crystallographic data in CIF or other electronic format see DOI: 10.1039/b801513a.

1 (a) S. Kawi and B. C. Gates, Clusters and Colloids: From Theory to Applications, ed. G. Schmidt, Wiley-VCH, Weinheim, 1994, ch. 4, p. p. 298; (b) P. Zanello, S. Tamburini, P. A. Vigato and G. A. Mazzocchin, Coord. Chem. Rev., 1987, 77, 165; (c) A. P. Alivisatos, J. Phys. Chem., 1996, 100, 13226; (d) A. Huignard, T. Gacoin and J.-P. Boilot, Chem. Mater., 2000, 12, 1090; (e) J.-C. G. Bünzli and C. Piguet, Chem. Rev., 2002, 102, 1897.

2 N. Sabbatini, M. Guardigli and J. M. Lehn, Coord. Chem. Rev., 1993, 123, 201

3 (a) I. A. Setyawati, S. Liu, S. J. Rettig and C. Orvig, Inorg. Chem., 2000, 39, 496; (b) T. Yamada, S. Shinoda, H. Sugimoto, J.-i. Uenishi and H. Tsukube, Inorg. Chem., 2003, 42, 7932; (c) X.-F. Li, W.-S. Liu, Z.-J. Guo and M.-Y. Tan, Inorg. Chem., 2003, 42, 8735; (d) Z.-P. Zheng, Chem. Commun., 2001, 2521; (e) J. M. Lehn, Supramolecular Chemistry: Concepts and Perspectives, VCH, Weinheim, 1995; (f) C. Piguet and J.-C. G. Bünzli, Chem. Soc. Rev., 1999, 28, 347; $(g)$ J.-C. G. Bünzli and C. Piguet, Chem. Soc. Rev., 2005, 34, 1048; (h) C. Piguet, J.-C. G. Bünzli, B. Donnio and D. Guillon, Chem. Commun., 2006, 3755; (i) C. Piguet, Chimia, 1996, 50, 144; (j) P. Guerriero, S. Tamburini and P. A. Vigato, Coord. Chem. Rev., 1995, 139, 17.

4 (a) X.-P. Yang, B. P. Hahn, R. A. Jones, W.-K. Wong and K. J. Stevenson, Inorg. Chem., 2007, 46, 7050; (b) X.-P. Yang, R. A. Jones, J. H. Rivers and R. P.-J. Lai, Dalton Trans., 2007, 3936; (c) X.-P. Yang, B. P. Hahn, R. A. Jones, K. J. Stevenson, J. S. Swinnea and Q.-Y. Wyu, Chem. Commun., 2006, 3827; (d) X.-P. Yang, R. A. Jones, W.-K. Wong, V. Lynch, M. M. Oye and A. L. Holmes, Chem. Commun., 2006, 1836; (e) W.-K. Wong, X.-P. Yang, R. A. Jones, J. H. Rivers, V. Lynch, W.-K. Lo, D. Xiao, M. M. Oye and A. L. Holmes, Inorg. Chem., 2006, 45, 4340; ( $f$ ) X.-P. Yang and R. A. Jones, J. Am. Chem. Soc., 2005, 127, 7686.

5 Fluorescence quantum yields were determined relative to $\left[\mathrm{Ru}(\text { bipy })_{3}\right] \mathrm{Cl}_{2}$ in water (bipy $=2,2^{\prime}$-bipyridine; $\Phi_{\mathrm{em}}=0.028$ ): K. Nakamaru, Bull. Chem. Soc. Jpn., 1982, 5, 2697.

6 S. Petoud, S. M. Cohen, J.-C. G. Bünzli and K. N. Raymond, J. Am. Chem. Soc., 2003, 125, 13324.

7 F. Lam, J.-X. Xu and K. S. Chan, J. Org. Chem., 1996, 61, 8414.

8 G. M. Sheldrick, SHELXL-97, Program for refinement of crystal structures, University of Göttingen, Germany, 1997. 